\title{
Razvojni integrirani kurikulum u umjetničkim područjima - poli-art model s modulima
}

Filozofski fakultet Sveučilišta u Splitu, Split, 2016., 268. str.

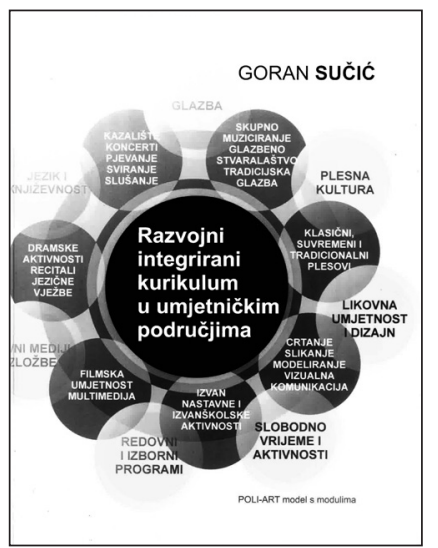

državnim i međudržavnim natjecanjima. Dobitnik je nagrade „Marko Marulić“ za postignuća u znanosti, zatim nagrade „Ivan Filipović“ za postignuća i doprinos visokom obrazovanju, priznanja grada Splita i nagrade Splitsko-dalmatinske županije za doprinos u kulturi te drugih nagrada i priznanja za znanstveni i umjetnički rad.

Znanstvena monografija organizirana je u devet naslova, odnosno poglavlja s podnaslovima. Autor sistematično i logičnim slijedom strukturira naslove uvodeći čitatelja u teorijsku osnovu vezanu za temu i problematiku monografije. Nakon „Uvodnih razmišljanja autora“ slijede poglavlja: „Umjetnost: sloboda, stvaralaštvo, estetika“; „Kurikulum: kurikulum i njegova povijesna i teorijska polazišta“; „Uvod u psihologiju glazbe“; „Glazba“; „Jezik, književnost i glazba“; „Likovnost i design“; „Plesna kultura - pokret na glazbeni poticaj“; „Integrirani procesi - suodnosi“; „Kurikulum kao produkt interesa učenika“.

U prvom se poglavlju ističe važnost umjetnosti u odgoju i obrazovanju djeteta kao iznimno važnog segmenta za njegov razvoj. Zadatak umjetničkog odgoja razvijanje je kreativnosti kod djece te je u umjetnosti naglasak prvenstveno na osjetilnom, a tek onda na spoznajnom. Time se razvijaju apstraktno i kritičko mišljenje, potiče se stvaralaštvo i istraživanje, pridonosi se emocionalnom razvoju te jačanju samopouzdanja i samopoštovanja.

U izdanju Filozofskog fakulteta u Splitu 2016. godine objavljena je znanstvena monografija Razvojni integrirani kurikulum u umjetničkim područjima - poli-art model s modulima autora dr. sc. Gorana Sučića, znanstvenika i umjetnika koji ima bogato iskustvo u odgojno-obrazovnom radu s učenicima osnovnih škola i studentima, kojima i danas predaje na Filozofskom fakultetu u Splitu. Cijeli život dr. sc. Goran Sučić bavi se umjetnošću, posebice likovnom i glazbenom te redovito sudjeluje na brojnim izložbama i kolonijama. Autor je i skladatelj većeg broja glazbenih projekata, glazbenih obrada te stručnih i znanstvenih članaka. Dr. sc. Goran Sučić hrvatski je skladatelj čija su djela obavezna glazbena literatura te se izvode na brojnim 
Povijesni razvoj kurikuluma te pojmovno određenje i struktura kurikuluma, što je predmet drugoga poglavlja, uvod je u problematiku kojom se autor bavi, nudeći kasnije svoje ideje i vidove promjena u području kurikuluma umjetničkih područja identificiranjem problema postojećeg sustava školstva, kao što su osiromašen i centraliziran sustav, zapuštanje odgojne i kulturološke uloge škole, opće nezadovoljstvo učenika, ravnatelja i učitelja. Suvremeni integrirani kurikulum ishodište temelji u cjeloživotnom obrazovanju kao nužnoj promjeni u smjeru odgoja i obrazovanja koje u središte stavlja učenika, kojeg se oslobađa od usvajanja velike količine informacija i njihove reprodukcije.

Autor polazi od toga da pravo na doživljaj umjetničkog djela ima svako dijete, talent i razvijene glazbene sposobnosti nisu privilegija pojedine djece koja umjetnost bolje razumiju ili se bolje i lakše umjetnički izražavaju. U trećem poglavlju jasno definira što je to talent, a što su glazbene sposobnosti, njihovu strukturu te faktore koji utječu na razvoj sposobnosti i na koji se način mjere te kako rezultati mjerenja pomažu učiteljima u unapređenju rada s djecom, između ostalog, i kod primjene glazbe za brže i lakše usvajanje stranih jezika i drugih nastavnih sadržaja.

„Laka glazba“ i „kulturna industrija“ odgajaju mlade naraštaje za beskompromisno usvajanje onoga što im se nudi s ciljem sve veće financijske dobiti. Glazba kao umjetnost u odgojno-obrazovnom procesu nastoji ponuditi rješenje za takvu situaciju stavljajući u središte dijete, koje uči kako doživjeti, osjetiti i čuti neko glazbeno djelo. Autor u ovom poglavlju, „Glazba“, navodi važnost alternativnog odgoja koji učeniku omogućuje odabir one vrste umjetnosti prema kojoj ima najviše afiniteta, dajući mu pritom slobodu u doživljavanju i izražavanju. Nastava glazbe u školi u prvi plan stavlja multikulturalnost, čime se učenike upoznaje s bogatstvom njihovog vlastitog kulturnog nasljeđa te onog drugih naroda. Upravo otvoreni koncept razvojnog integriranog kurikuluma umjetničkih područja nudi module - glazba, jezik i književnost, likovnost i dizajn, plesna kultura - koje učenici odabiru prema vlastitim interesima. Takav pristup može se promatrati s pedagoško-psihološkog, umjetničko-estetskog aspekta, a autor nadodaje i s kulturološko-odgojnog aspekta, s ciljem razvoja kulturnih i odgojnih navika. Djeca iskazuju golemo zanimanje za sviranje pojedinih instrumenata, što im se tijekom nastave glazbene kulture ili izvannastavnih aktivnosti vrlo rijetko omogućuje. Glazbene sastavnice u razvojnom integriranom kurikulumu - pjevanje, glazbeno stvaralaštvo, pokret na glazbeni poticaj, glazbeni recital i dramatizacija te sviranje, autor navodi kao idealne vrste aktivnosti među kojima dijete može samo birati one kojima se želi baviti, a koje će voditi kompetentni učitelji odnosno nastavnici. Nastavu umjetničkih predmeta potrebno je osloboditi nepotrebnih teorijskih sadržaja jer se na taj način dijete udaljuje od doživljaja samog umjetničkog djela. Glazba, osim što potiče pozitivne emocije, stvara osjećaj zajedništva, pripadnosti i tolerancije te ima i terapeutska svojstva. Redovnu nastavu sve više pohađaju djeca s nekim oblikom smetnje ili teškoće u razvoju i učenju, gdje se uviđa značaj glazboterapije kao neizostavnog dijela razvojnog integriranog kurikuluma. Glazbena terapija djeci omogućuje ublažavanje govornih nedostataka, poticanje pozitivne svijesti o sebi, poboljšanje motoričkih funkcija, potiče komunikaciju te ima mnoge druge pozitivne učinke. Kako bi se terapija umjetnošću mogla provoditi u školama, potrebno je osposobiti studente posebice učiteljskih i umjetničkih studija za rad na takav način. 
U petom poglavlju, ,Jezik, književnost i glazba“, autor opisuje povezanost slike, glazbe i teksta. Opisujući povezanost glazbe i učenja materinskog i stranog jezika prikazom rezultata istraživanja nekoliko istraživača, autor u ovom dijelu iznosi rezultate i vlastitog istraživanja koje je slične tematike. Istraživanje je provedeno u osnovnim školama Splita, Zadra i Šibenika te se zaključuje kako učenici koji sviraju neki instrument u glazbenim školama bolje i lakše usvajaju sadržaje stranih jezika od onih koji ne pohađaju glazbenu školu.

U šestom poglavlju, „Likovnost i design“, multidisciplinarnost i multikulturalnost u područjima umjetnosti autor ističe kao važne odrednice nastave umjetničkih predmeta, posebice likovne i glazbene kulture, gdje je zastupljeno slušanje kvalitetnog glazbenog djela na nastavi likovne kulture kao poticaj za likovno izražavanje. Povezanost područja umjetnosti potrebno je ostvariti prirodno, ne kao zamjenu, nego pronalaskom dodirnih točaka. Autor sažeto prikazuje specifičnosti nastavnog predmeta likovne kulture te određuje njegov cilj i zadatke.

Autor u poglavlju „Plesna kultura - pokret na glazbeni poticaj“ nastoji istaknuti važnost plesa kao dijela umjetničkog izričaja koji je često zapostavljen, a sastavni je dio uglavnom tjelesne i zdravstvene kulture. Neupitan je pozitivan utjecaj plesa na psihofizički razvoj djece, dok autor navodi kako fakulteti kao što su glazbene akademije i učiteljski studiji još uvijek nemaju u svojem programu kolegij koji bi osposobljavao studente za rad u području plesne kulture. Promjene u umjetničkom području značile bi uključivanje plesnih sastavnica - tradicijskih plesova, estetske gimnastike, folklora, suvremenog plesa, klasičnog plesa i baleta - u kurikulum, organizirane kao modul plesa. Prije zaključka poglavlja, autor prikazuje nekoliko relevantnih istraživanja koja potvrđuju važnost bavljenja plesom, njegovog pozitivnog utjecaja i ističe kako bi se plesni sadržaji svakako trebali uvrstiti u nastavni program povezivanjem tog dijela umjetnosti s ostalim predmetima.

U pretposljednjem poglavlju nudi se rješenje za problematiku opisanu u prethodnim poglavljima. Razvojni integrirani kurikulum u umjetničkim područjima u središte stavlja svako dijete, koje se potiče da otkriva i razvija interese, sposobnosti i sklonosti prema svim vrstama umjetnosti. Napuštanjem teorijskog dijela koji je zastupljen u programu umjetničkih predmeta osnovnih i srednji škola autor u prvi plan stavlja mladu osobu i njezine interese, ne ograničavajući je u vlastitom doživljavanju umjetnosti. Umjetnički bi predmeti, između ostalog, trebali odgojiti mladog čovjeka da želi sudjelovati u umjetničkim aktivnostima, posjećivati koncerte, izložbe, a to je teško postići nastavom koja se održava jednom tjedno i koja je u golemom obimu prožeta teorijskim činjenicama. Rješenje autor vidi i u drugačijoj organizaciji izborne nastave te u izvannastavnim i izvanškolskim aktivnostima. Navedene aktivnosti koje bi se provodile bile bi praćene i vrednovane, a ocjena bi ulazila u konačan prosjek ocjena, što čini novinu u našoj pedagoško-obrazovnoj praksi. Interdisciplinarno i multidisciplinarno povezivanje umjetničke grupe predmeta značilo bi njihovu međusobnu prožetost, gdje nije jasno određena granica između predmeta. Mišljenje nastavnika o nastavnim programima autor je potkrijepio i empirijski, navodeći za svaki predmet osnovne škole nanizana mišljenja nastavnika, gdje se kao osnovni problem navodi horizontalna i vertikalna nepovezanost predmeta. 
Posljednje poglavlje znanstvene monografije od izuzetne je važnosti jer prikazuje rezultate istraživanja koje je autor proveo i kojim dokazuje da nastavnici imaju potrebu za poli-art modelom kao integriranim umjetničkim područjem i da prihvaćaju takvu novu mogućnost u organizaciji nastavnog programa umjetničkog područja. Ispitanici, nastavnici, učenici, studenti, smatraju da umjetničke predmete treba integrirati u poli-art model te smatraju da bi takav model više motivirao učenike od dosadašnjeg klasičnog modela. Poli-art modelom, smatraju ispitanici, učenicima će se olakšati i približiti umjetnost, a smatraju da umjetničko područje umjesto teorije treba pružiti doživljaj, ugodu i razvoj duhovnih i estetskih vrijednosti. Rezultati istraživanja pokazali su potrebu uvođenja poli-art modela i u strukovne škole, u kojima umjetničko područje uopće nije predviđeno nastavnim planom i programom. Učenici strukovnih škola uviđaju važnost edukacije iz umjetničkog područja te iskazuju zanimanje za odlaske i sudjelovanje na kulturnim događanjima i sviranje nekog instrumenta po vlastitom izboru. Ispitanici su iskazali pozitivan stav prema izvannastavnim, izvanškolskim i slobodnim aktivnostima koje bi se ocjenjivale i suglasni su s napuštanjem tradicionalnog sustava u svrhu ostvarivanja doživljaja u umjetničkim predmetima.

Izuzetno brz tehnološki razvoj, ekonomske i društvene promjene zahtijevaju promjenu postojećeg odgojno-obrazovnog sustava. Današnja djeca već od najranije dobi uče koristiti suvremenu tehnologiju, gdje im je u vrlo kratkom vremenu dostupan velik broj informacija, stoga su upravo mediji najzabavniji i najpopularniji izvor znanja i zabave. Škola je u današnje vrijeme mjesto gdje se u prvi plan stavlja spoznajna komponenta nastave, a odgojna, kulturološka i umjetnička zanemarene su. Autor u monografiji naglašava važnost svih područja umjetnosti u razvoju učenika u mlade osobe s didaktičkog, kulturno-umjetničkog i duhovno-misaonog aspekta. Kako bi se navedeno postiglo, umjetnički predmeti više ne bi trebali biti zatvoreni i strogo određeni, već bi se prožimanjem sadržaja umjetničkih predmeta, brisanjem njihovih strogo određenih granica i korištenjem suvremenih metoda poučavanja trebao otvoriti put ka integriranom kurikulumu poučavanja umjetnosti. Učenike i njihov interes stavlja se u središte nastavnog procesa, gdje svrha nije usvajanje činjeničnih znanja, već svakom djetetu dati mogućnost doživljavanja umjetnosti, bez obzira na razinu njegovih sposobnosti i talenata. Problem nasilja u školama i sve većeg broja djece s teškoćama u učenju i ponašanju traži rješenje, koje autor vidi u primjeni umjetnosti u terapijske svrhe. Učitelj kao važan faktor može sudjelovati u prepoznavanju teškoća i njihovu rješavanju putem umjetnosti tek ako ima adekvatno obrazovanje vezano za to područje. Autor navodi i potrebu za takvom vrstom edukacije na učiteljskim fakultetima i umjetničkim akademijama kako bi se studente osposobilo za rad na takav način. Osim teorijskog dijela monografije vezanog za problematiku te vrijednog istraživačkog rada koji je proveo sam autor, doprinos ove monografije znanosti otvaranje je novih perspektiva u ustroju novog oblika odgojno-obrazovnog sustava umjetničkog područja prema poli-art modelu, koji autor nudi kao vlastiti projekt i odgovor na probleme prisutne u tradicionalnom modelu. Suština poli-art modela objedinjavanje je svih umjetničkih područja, postavljanje učenika i njegovih interesa u središte zanimanja, pri čemu ga se potiče da doživljava, gleda, djeluje i gdje se njegove izborne, izvannastavne i izvanškolske aktivnosti ocjenjuju, a svaki uspjeh adekvatno nagrađuje. Formiranje mladog čovjeka koji je svjestan, tolerantan i osjetljiv za potrebe drugih, koji komunicira s umjetnošću te aktivno sudjeluje u kulturnom 
Životu, krajnji je cilj koji se nastoji postići odgojem i obrazovanjem putem umjetnosti. Ova znanstvena monografija nezaobilazna je literatura koja daje novi pogled na umjetnička područja u odgoju i obrazovanju, a od velikog je značaja studentima učiteljskih fakulteta i umjetničkih akademija, učiteljima, nastavnicima, glazbenim i likovnim pedagozima te svim odgojno-obrazovnim djelatnicima i onima koji se na bilo koji način u svom radu susreću s tom tematikom.

Azra Magdić, doktorandica Filozofski fakultet Sveučilišta u Splitu 